\title{
ETHNICITY AND THE JURY SYSTEM
}

\section{Ashton Wesley Welch Creighton University}

\begin{abstract}
Discrimination in the jury system has been a matter of constitutional and ethical concern at least since the mid-nineteenth century. Ethnic and linguistic minorities have been disadvantaged by the use of the peremptory challenge, statutory requirements, and administrative practices which compromised the Sixth Amendment provision for a jury of one's peers with its implication for juror impartiality. Attacks on the discriminatory applications of those systems and practices resulted in reduction, as gradual as it was, of the exclusionary practices. Batson vs Kentucky made the Sixth Amendment guarantee more reachable for ethnic and linguistic minorities.
\end{abstract}

The campaign to eliminate ethnic bias from the jury system and to make panels conform more closely to the ideal of trial by a jury of one's peers has been long and tortuous. As with much of the legal system the entire system of trial by jury is often manipulated to discriminate against members of cognizable groups including ethnic and linguistic minorities. That manipulation of the system occurs is not surprising. The selection process, the wider judicial system and its traditions, and the pluralistic nature of the American nation lend themselves to it. The United States Department of Justice counted ninety-two different methods to select jurors in the federal system. ${ }^{1}$ When the vast panoply of state and local courts are added to the federal system the variety becomes almost unfathomable.

Trial by jury is rooted in law and tradition. It is widely 
accepted that the practice existed in England by the end of the thirteenth century. English settlers took it to the colonies in the early seventeenth century. Colonial practices concerning juries and trial procedures were enshrined in the Fifth, Sixth, and Seventh amendments of the United States Constitution after the Revolution. The Sixth guarantees the right to a trial by jury with the provision that "In all criminal prosecutions, the accused shall enjoy the right to a speedy and public trial, by an impartial jury of State and district wherein the crime shall have been committed...." The Constitution leaves the operation of state and local courts, including aspects of forming juries, to the states for non-federal matters hence the great variety of jury practices at the state and local levels.

Some uniformity exists in the jury selection process nonetheless. In most jurisdictions there are three major phases to the process. First there is identification of a qualified pool. Membership is obtained from lists of payers of property taxes, registered voters, holders of valid driver licenses, names contributed by community leaders, telephone subscribers, or from some other repository taken to be representative of the public at large. Creation of the venire is the second step. Some members of the pool identified in phase one are summoned for a specific trial. Some jurisdictions permit veniremen, those called for phase two, to disqualify themselves on presenting of a valid excuse. Physical condition, occupation, and employment are but three of the acceptable myriad of valid excuses. The last step is the voir dire. Voir dire means literally "to see to tell." In it potential jurors taken from the venire are subjected to oral questioning by the judge, by attorneys to the suit, or by all of them. During the voir dire or at its end the venire pool is culled to provide the actual trial jury and alternates if the jurisdiction provides for alternates.

The reduction of the venire to produce the trial jury is achieved mainly through a system of challenges and additional disqualifications. There are two types of challenges: cause and peremptory. A challenge for cause may be invoked whenever a member of the venire indicates or demonstrates some actual or potential partiality to the case. Each side of a case can use an unlimited number of challenges for cause. Peremptory challenges on the other hand are limited. The 
number is established by the political or judicial jurisdiction. Traditionally attorneys from either side could use them to eliminate prospective jurors from the venire pool without having to state either cause or explanation. A peremptory challenge is therefore a mechanism to eliminate those prospective jurors who the attorney believes, but cannot or is unwilling to prove, will act less favorably than other members of the venire to his or her client.

The peremptory challenge is rooted in tradition. According to Blackstone, it was in use in England at the beginning of the fourteenth century. As with many other aspects of American legal procedures, the practice immigrated to the Americas with English colonists. The United States Supreme Court categorized it to be "a necessary part of trial by jury." Until the 1980s the Court almost routinely rejected attacks on the use of peremptory challenges even when it was obvious that peremptories were used to skew the replication of the ethnic quilt of American society in juries. ${ }^{2}$

The issue of ethnicity and juries arose shortly after the Constitution was ratified. As in much of the debate on American race relations the issue was framed mainly in the White-Black dichotomy. Native Americans and Asian mattered little. Jury service was tied to citizenship, and few of either group attained citizenship until relatively recently. While Congress granted citizenship to members of some tribal groups in the nineteenth and early twentieth centuries, Native American citizenship was recognized only in 1924 and fully settled in 1940 by the Nationality Act. Asians became eligible for citizenship even later. As for African Americans, federal law was ambiguous on the nature of slaves: they were both chattel and persons. The Constitution and fugitive slave acts, most notably the original Fugitive Slave Law of 1793, mandated the return of escaped slaves. Without exception all states provided for trial by jury. Constitutions of the various states did not deviate much from the Seventh Amendment provision that "in suits of common law, where the value in controversy shall exceed twenty dollars, the right of trial by jury shall be preserved ..." Theoretically, therefore, questions on ownership of alleged slaves could be answered by juries. Within their borders free states tended not to recognize the chattel quality, 
and therefore the monetary value, of a slave. Such states regarded slaves as persons before the law. For purposes of recovery slave owners also emphasized the human aspect of alleged fugitives. As an individual a reputed fugitive slave was entitled to a jury trial in free states. Federal law took precedent on this issue however. Consistent with the Article IV Section 2 of the Constitution, apprehended alleged slave fugitives were extradited or otherwise returned to the purported place of their escape without trial.

In the 1830s some states enacted personal liberty laws to frustrate the slave returning procedures. Personal liberty laws reversed that basic tenet of the slavery era that African Americans were slaves unless it was proven to the contrary. Not only did they take a black person to be free unless and until it was established that he or she was a slave, such statutes also provided for jury trials before an alleged fugitive could be removed from the state. Most proponents of personal liberty laws were not concerned with the civil rights and duties of African Americans however. Motivated primarily by the issue of states rights, some advocates of personal liberty laws objected to what they regarded as needless federal intrusion into prerogatives of the states though the national government's enforcement of the Fugitive Slave Act. They also believed that the jury trial requirement would dissuade bounty hunters and other agents of slave masters.

Motivations aside, the Supreme Court and the Congress undermined personal liberty laws. In Prigg v. Pennsylvania, 1842, while it affirmed the constitutionality both of the Fugitive Slave Law and personal liberty statutes the Supreme Court invalidated trial and jury provisions of the latter. 3 The Court relied heavily on Article IV Section 2 which held that:

No person held to Service of Labor in one State, under the Laws thereof, escaping into another, shall, in Consequence of any Law or Regulation therein, be discharged from such Service or Labor, but shall be delivered up on Claim of the Party to whom and Service or Labor may be due.

In the Court's thinking, Article IV Section 2 vitiated any state law or holding that conferred freedom to an alleged fugitive slave. Hence it nullified the issue of a jury trial for any pre- 


\section{Ethnic Studies Review Volume 24}

sumed fugitive. Congress reaffirmed the right to remove alleged fugitive slaves without trial in 1850 when it re-authorized the fugitive slave act.

While it became embedded in the debate over slavery, the issue of African Americans and juries was in no means limited to practices linked to the "peculiar institution." It should be remembered that federal citizenship was relatively inconsequential in contrast to state citizenship on issues most likely to involve the judiciary. In much of the slave-free North states continued to make jury service a prerogative of Whites. For example, in 1807, as Congress debated termination of the international slave trade, New Jersey, with a tradition of choosing jurors from lists of qualified voters, adopted a new constitution with a white suffrage only requirement. In a more direct manner, Ohio enacted a law in 1831 to remove the right of African Americans to sit on juries. And it was only on the eve of the Civil War, in 1860, that Massachusetts's social exclusion of African Americans as jurors was breached.

The question of ethnic minorities and juries took new directions in the aftermath of the Civil War. With the abolition of slavery, whether African Americans were equal before their respective states' laws, with the same rights, privileges and obligations as Whites, including trial by and service on juries, became an issue of presidential reconstruction. States reconstructed under the Lincoln-Johnson plans answered no. Moreover federal juries in such states tended to be all-white and it was common for them to return what might be termed anti-black and anti-Union decisions. In the beginning the issue was justice for African Americans at the hands of all-white juries in the ex-confederacy. The matter soon expanded to the right of African Americans to serve on juries in state and federal courts and the quality of justice for all. The inability of federal prosecutors to get convictions of ex-Confederates by allwhite juries was cited by African Americans, Northerners, and their sympathizers as proof of the failure of southern justice. Radical Republicans and many Northerners thought that African Americans should have been given full access to juries if for no other reason than to balance the scales for the government. White Northerners assumed that interracial juries would provide more even-handed justice for African Americans 
as well as for Whites. Buttressed by their notions of equality before the law and the unfairness of justice in the South, Radical Republicans drafted the Fourteenth Amendment and enacted a host of statutes, including the Civil Rights Acts of 1866 and 1875 and the Enforcement Act of 1872, designed to enhance and protect the citizenship rights of Blacks. The Civil Rights Act of 1875 made it a criminal offense to exclude anyone from jury service on grounds of race. It also included the corrective provision that in instances of discrimination in the selection process any party to a suit could petition to have the case transferred to a federal district court.

The transfer and criminal provisions of the Civil Rights Act of 1875 had little meaning from the time they were enacted. Attorneys found it difficult to prove that racial prejudice was a reason African Americans were omitted from juries. As Reconstruction waned, ex-Confederates and their spiritual allies reestablished white supremacy across the South: some did so by stealth; others straightforwardly discriminated against African Americans without fear of punishment or censure. Some localities enacted statutes that limited the rights and privileges of African Americans. On the judicial front, the discriminatory drive was slowed by the Supreme Court in 1880 in Ex parte Virginia with its reversal of decisions by Virginia judges to limit juries in their court rooms to white men only. 4

In Strauder v. West Virginia, also decided in 1880, the High Court invalidated state statutes which limited jury service to white males as a violation of the Equal Protection Clause of the Fourteenth Amendment. An African American, Strauder was indicted, tried, and eventually convicted by an all-white jury in a West Virginia county court. Prior to the jury's deliberation his attorney protested against the exclusion of African Americans from the jury. He invoked the transfer provision of the Civil Rights Act of 1875 and petitioned to remove the case to a federal court. The trial court denied his objection and the trial proceeded. The attorney renewed his protests after the jury rendered its decision. In additional motions, he moved to quash the conviction and asserted that the act which limited jury service to Caucasian males violated the Equal Protection Clause because it denied his client the right of trial by a jury inclusive of his racial peers as afforded to Whites. The trial and superi- 
or state courts rejected all of his motions. A divided United States Supreme Court concluded otherwise: it held that defendants are entitled to juries composed of their "neighbors, fellows, associates, persons having the same legal status in society as ... " themselves. Writing for the majority, Justice William Strong added that to deny African Americans the right to participate in the administration of law branded them as inferior and contributed to inciting "that race prejudice which is an impediment to securing to individuals of the [Negro] race that equal justice which the law aims to secure to all others." Any positive potential of Strauder and its progenies was not realized until relatively late because a defendant had to show intentional discrimination by court officials. Furthermore adhering to a principle enunciated in Smith V. Mississippi, 1896, the Court operated on the presumption that a state's action was constitutional and correct unless a petitioner proved otherwise. 5

The Virginias were but two of the states that kept African Americans ineligible for jury duty. In the Strauder decision the Court ruled that it was a clear denial of equal protection of the laws for a black defendant to stand trial before a jury from which all African Americans were excluded by state statute. The Court posited that "the very idea of a jury is a body of men composed of the peers or equals of the person whose rights it is selected or summoned to determine ...." And, cognizant that "prejudice often exists against particular classes within the community, which sway the judgment of jurors," the Court asked rhetorically:

Is not protection of life and liberty against race or color prejudice, a right, a legal right, under the constitutional amendment? And how can it be maintained that compelling a colored man to submit to a trial for his life by a jury drawn from a panel from which the State has expressly excluded every man of his race, because of color alone, however well qualified in other respects, is not a denial to him of equal legal protection? 6

Consistent with constitutional law, Strauder was a solution for a specific problem. Hence while Strauder seemingly made it clear that states could not use legislation to bar African Americans from jury service the ruling did not address other 
strategies contrived to produce the all-white jury. Delaware, for example, allowed local jurisdictions to select "sober and judicious" persons for jury service from taxpayer lists. Under that system, black taxpayers were ostensibly qualified for jury service but were rarely selected for the jury pool. In ruling to a challenge of the continuing exclusion of African Americans from juries, the Delaware Supreme Court agreed with the State's contention that very few of the African Americans in Delaware were intelligent, experienced, or moral enough to serve as jurors. Seeking to rectify discriminatory administration of racially fair jury selection laws to achieve discriminatory results the Court extended the premise of Strauder in Neal $v$ Delaware. ${ }^{7}$

Neal was a hollow advance however. The same day that it handed down the Strauder and Ex parte Virginia decisions the Court, in Virginia $v$ Rives, emasculated the transfer provision of the Civil Rights Act of 1875 , ruling that the absence of African Americans from a particular jury was not persuasive proof of illegal state discrimination. The Court stated clearly that while black defendants are entitled to juries chosen free of discrimination against members of their race, no black defendant is entitled to a jury which contains members of his or her race. 8 Thereafter a case could not be transferred to federal courts before a jury was impaneled.

The causative elements in Strauder and Rives were indicators of the drift toward "separate but equal." In the re-casted inequality, Southern states limited political participation of African Americans through the use of comprehension tests, poll taxes, and other well-chronicled means to purge African Americans from the political system. In spite of the connective links between political participation and jury service the Supreme Court found discriminatory political statutes constitutional. The segregationist drive to exclude African Americans from juries received heightened sanction in 1898 with the decision in Williams $v$. Mississippi in which the Court upheld Mississippi's use of gerrymandering, poll taxes, and subjective literacy tests to limit or prevent the political participation of African Americans and especially to prevent them from registering to vote. Then, having already placed its constitutional imprimatur on Mississippi's political practice, the Court held 


\section{Ethnic Studies Review Volume 24}

that since the state's voting statutes were constitutional under the Fifteenth Amendment, its law restricting jury service to registered voters was likewise constitutional even if few African Americans met the registration requirements. Justice Oliver Wendell Holmes seemingly expressed the Court's reasoning with his decision in Giles v. Harris; he wrote that the Court lacked the power to protect the rights of African Americans when overwhelming numbers of Whites were determined to violate them. ${ }^{9}$ A number of Southern states followed the Mississippi example after the Williams decision. The end result was with the severe reduction of the number of qualified black registrants the potential pools of black jurors were much restricted since voter registration lists were the most popular source of potential jurors.

Some African Americans managed to overcome the hurdles designed to prevent or to limit their political participation and, ostensibly, therefore, some were eligible for jury duty. It was rare, however, for many of them to be summoned for duty and rarer still for any of them to serve. Court officials and others with ancillary judicial functions routinely skipped over the seemingly qualified few until 1935 with the decision in Norris $v$. Alabama. ${ }^{10}$

Norris lessened the burden of proof for defendants by forcing states to defend practices which had discriminatory impacts. For the first time the Court suggested that lower courts should be guided by statistics when considering objections to alleged discriminatory uses of peremptory challenges. The infamous "Scottsboro boys" case, Norris was an appeal by a black male of his conviction by an all-white jury of raping a white female. In a partial reversal of the Rives doctrine, the Supreme Court held that a defendant could prove a prima facie case of discrimination if he or she could demonstrate (a) the existence of a substantial number of his or her cognizable group in the community and (b) its total exclusion from jury service. Upon a defendant demonstrating those "facts," the burden of proof shifted to the state to prove that the exclusion was not a product of discrimination. The Court noted that general denials of unintentional discrimination could not satisfy the burden of rebuttal.

Norris was but an opening. As before, officials altered dis- 
criminatory practices to satisfy specific objections of the Court but without intention to institute jury equality. A common adjustment was to add a few minorities to the identified pool and occasionally to jury panels. Often times minorities were added to general pools and removed before or during the voir dire. Such subterfuge did not go unchallenged. Advocates of minority inclusion attacked the chicanery. As cases arose that involved token inclusion of minorities, rather than their total exclusion, the Supreme Court broadened the Norris thesis, first, to instances of gross under-representation 11 and, then, to cases where a substantial disparity between minority group members in the community and on the jury list "originated, at least in part, at the point in the selection process where the jury commissioners invoked their subjective judgement rather than objective criteria." This drift culminated in 1977 with the ruling in Castaneda v. Partida, a decision that held a prima facie proof of discrimination was established by a demonstration of prolonged under representation from a cognizable group. ${ }^{12}$

The Court had not become tolerant of proportional representation however: far from it. In 1965 in Swain v. Alabama it considered the use of the peremptory challenge for discriminatory purposes for the first time. Swain represented still another appeal of a black male convicted by an all-white jury of the rape of a white female. No black person had served on a petit jury in Talladega County, where the trial was held, in the fifteen years before 1965 although twenty-six percent of those qualified for jury service were black. In the voir dire, the prosecutor used his peremptory challenges to eliminate all six African Americans on the venire. On appeal the Supreme Court was asked whether the Equal Protection Clause prevented the total exclusion of African Americans from a petit jury. Counsel for Swain argued that this was not a singular case of utilizing peremptories in a racially discriminatory fashion. Although it agreed with defense counsel that no African American had sat on any type of jury in the county in modern times, the Court, noted that in several cases the defense had agreed with the prosecution not to include African Americans in juries, held that Swain's attorney had not proven that the state alone was at fault for the discriminatory results. The Court observed that a Fourteenth Amendment issue would be raised if the defendant 
could prove that regardless of the charge or the parties to the crime Talladega County prosecutors used their challenges systematically to eliminate all African Americans on venires from duty on juries. However, the action was not unconstitutional if the state limited its exclusion of black veniremen to cases with black defendants "for the question a prosecutor or defense counsel must decide is not whether a juror of a particular race or nationality is in fact partial, but whether one from a different group is less likely to be."

Holding that the defendant had failed to prove that the prosecution used its peremptory challenges to deliberately exclude African Americans from the jury, the Court declared that the "presumption in any particular case must be that the prosecutor is using the State's challenges to obtain a fair and impartial jury. ... . The presumption is not overcome [even if] all Negroes were removed because they were Negroes." To overcome the presumption, the Court ruled, a defendant had to demonstrate that the state followed a consistent pattern of discrimination in "case after case, whatever the circumstances, whatever the crime and whoever the defendant or victim." Moreover, the defendant had to differentiate between the defense's and prosecution's peremptory challenges in order to establish a discriminatory motive. ${ }^{13}$ No defendant was able to meet the standards of systematic exclusion established in the decision. Moreover, state and federal courts alike did not countenance presentation of evidence from only cases which involved black defendants. 14

Swain represented a judicial use of tradition. As early as 1883, in Bush v. Kentucky, the Court had ruled that the Constitution does not require that a trial jury must contain members of the same race as a party to a suit but simply prevents the state from arbitrarily eliminating members of her or his cognizable group. Bush was but one of a score of challenges to the system of peremptory challenges. The Court was adamant that the Constitution forbids the systematic exclusion of members of cognizable groups from jury panels without requiring inclusion of representation from groups in such bodies. The Court restated its position in Apodaca v. Oregon in which it held that no defendant had the right to "challenge the makeup of a jury merely because no members of his race are 
on the jury" for there is no constitutional requirement that every particular jury be representative. 15 Thus, while the Court accepted, for a time in Akins $v$. Texas, 16 the practice of the Jury Commissioner of Dallas County of never including more than a single African American in grand juries as a "good faith effort" in compliance with the ruling, in Hill $v$. Texas, 17 it eventually found the practice odious and unacceptable. According to Associate Justice Frank Murphy, the Equal Protection Clause guarantees "not only the right to have Negroes considered as prospective veniremen but also the right to have them considered without numerical or proportional limitation." As stated in Cassell v. Texas, it is unconstitutional to include a predetermined number of any cognizable group, even that to which a minority defendant belongs, for jurors "should be selected as individuals, on the basis of individual qualifications, and not as members of a race."18

While still reluctant to consider the use of peremptory challenges the Court addressed the notion of group affiliation more directly in 1954 in Hernandez $v$. Texas. Texas had continued to rely on the key-man system to select juries; community leaders provided jury commissioners with names for jury lists. Most key-men were White as were most of their identified prospects. Minorities especially persons of Mexican heritage were severely under represented in jury lists. In Hernandez the Court accepted the assertion that Mexican-Americans constituted a cognizable class. It then proceeded to rule that an administration of jury selection procedures so as to exclude MexicanAmericans or to minimize their participation was as much a violation of equal protection as if it had been done against AfricanAmericans. In the words of the Court:

When the existence of a distinct class is demonstrated, and it is further shown that the laws, as written or as applied, single out that class for different treatment not based on some reasonable classification, the guarantees of the Constitution have been violated. The Fourteenth Amendment is not directed solely against discrimination due to a two-class theory-that is, based upon differences between white and Negro. ${ }^{19}$

The Court also dealt with other procedural questions with 


\section{Ethnic Studies Review Volume 24}

bearing on juries and minorities. The right to invoke cause is premised on the realization that individuals hold prejudices that might hinder their ability to be fair and impartial. Prejudice can be ethnic and racial. While it does not guarantee perfection, the voir dire is an opportune process to discover any prejudice that might affect a juror's impartiality. Rules of judicial behavior restrict the questions which attorneys and judges might ask potential jurors however. Nevertheless in People v. Reyes,20 with Mexican nationals as defendants, in People v. Car Soy which involved Chinese,21 Horst $v$. Silverman,22 a case in which Jews were parties, and Aldridge v. United States, an appeal by an African American,23 the Court declared that there are special conditions when the "essential demands of fairness" command that veniremen be questioned about racial or ethnic prejudices. In a series of later decisions, the Court delineated the very limited circumstances when voir dire questioning to discern such biases is permissible. ${ }^{24}$

The High Court also held that illegal discrimination in constituting of either the grand or the petit jury mandates reversal of any resulting conviction25. Then going further, and casting aside technicalities, the Court in Turner $v$. Fouche 26 and in Carter v. Jury Commission 27 accepted the right of black citizens not directly involved in a specific exclusion case to challenge the systematic exclusion of African Americans from petit and grand juries. According to the Carter majority "Whether jury service be deemed a right, a privilege, or a duty, the State may no more extend it to some of its citizens and deny it to others on racial grounds than it may invidiously discriminate in the offering and withholding of the elective franchise."

The decision in Peters $v$. Kiff extended that rationale to Whites. In Peters, a white male defendant protested against the systematic exclusion of African Americans from the grand and petit juries which, respectively, indicted and tried and convicted him. Before his appeal could be considered on its merits, the question of whether white persons had standing to raise the issue of systematic exclusion of African Americans had to be decided. A divided Court said they did. Writing for the majority, Justice Thurgood Marshall held that:

When any large and identifiable segment of the community is excluded from jury service, the effect is to 
remove from the jury room qualities of human nature and varieties of human experience, the range of which is unknown and perhaps unknowable. It is not necessary to assume that the excluded group will consistently vote as a class in order to conclude, as we do, that its exclusion deprives the jury of a perspective on human events that may have unsuspected importance in any case that may be presented. ${ }^{28}$

President Lyndon B. Johnson echoed Marshall's position in his call for the Civil Rights Act of 1966. The Civil Rights Act of 1966 was motivated in part by a desire to eliminate discriminatory practices condoned by the Swain decision. The immediate inspiration behind the bill, however, was the acquittal of several white defendants charged with crimes against African Americans and civil rights workers by all-white juries. In recommending corrective action to Congress, President Johnson evoked parallels of the Reconstruction era's notion of community and community service, with the assertion that to deny

... jury service to any group deprives it of one of the oldest and most precious privileges and duties of free men. It is not only the excluded group which suffers. Courts are denied the justice that flows from impartial juries selected from a cross section of the community.

The people's confidence in justice is eroded.29

Title I deals with federal juries. It prohibits discrimination on account of color, race, religion, gender, economic status, or national origin. Its initial section reaffirms that "all litigants in Federal Courts entitled to trial by jury shall have the right to a jury selected from a cross section of the community in the district or division where the court convenes. ..." It declares that "all qualified citizens shall have the opportunity to serve on grand and petit juries" in federal courts and "shall have an obligation to serve when summoned." It also established procedures for the selection of jurors.

Title II aims to eliminate discrimination in state and local juries primarily through judicial, rather than administrative, means. Section 201 holds that

it shall be unlawful to make any distinction on account of race, color, religion, sex, national origin or economic status in the qualifications for service, and in the 
selection, of any person to serve on grand or petit juries in any state.

The Act commissions the Attorney General to sue in federal court

whenever there are reasonable grounds to believe that any person has engaged or is about to engage in any act or practice which would deny or abridge" any of the guarantees of Section 201." If it determined there were violations of the Act's jury provisions the court can force state officials to use "objective criteria" in formulating jury lists. 30

A number of states also moved to end the systematic abuse of the right to a jury of one's peers. California led the way. In People v. Wheeler the California Supreme Court ruled that the use of peremptory challenges to disqualify prospective jurors simply on grounds of group affiliation violated Article I Section 16 of the California Constitution. ${ }^{31}$ The California opinion also rested on Taylor $v$. Louisiana,32 a judgment by the United States Supreme Court that one's peers required trial juries and not merely venires to have a cross section of the population. The California jurists went further and added that a petit jury should reflect as ideally a cross section of the community as random selection would produce. Like the U.S. Supreme Court in Swain, the California court formulated standards to establish a prima facie condition to assert the use of peremptories in an ethnically biased manner. Either the defense or the prosecution can object to a seemingly discriminatory use of peremptories and neither side has to be a member of the cognizable group it claimed was illegally excluded. Massachusetts and New Mexico followed suit in Commonwealth v. Soares 33 and State v. Crespin 34 respectively. The Massachusetts court held peremptories could not be used in a fashion so as to make meaningless the state constitutional guarantee of a petit jury of one's peers or to infringe upon the state's Equal Rights Amendment which prohibits any abridging of equality on the basis of color, creed, gender, race, or national origin.

Wheeler, Soares, and similar decisions withstood attacks of their constitutionality in federal courts because they rested on their states' constitution and not on federal statutes. 
Though it continued to adhere to Swain the Supreme Court was not unalterably opposed to reconsidering its position. In the interim and over the repeated objections of justices William Brennan and Marshall, it waited to "allow the various states to serve as laboratories in which the issue receives further study before it is addressed by this Court" again. Joined by Brennan, Marshall attacked the majority's "experimentation with the rights, and lives of petitioners"; in his dissent in Gilliard v Mississippi he wrote:

When a majority of this Court suspects that such rights are being regularly abridged, the Court shrinks from its constitutional duty by awaiting developments in state or other federal courts. Because abuse of peremptory challenges appears to be most prevalent in capital cases, the need for immediate review in this Court is all the more urgent. If we postpone consideration of the issue much longer, petitioners in this and similar cases will be put to death before their constitutional rights can be vindicated. Under the circumstances, I do not understand how in good conscience we can await further developments, regardless of how helpful those developments might be to our own deliberations. 35

Marshall also chided his brethren that

there is no point in taking elaborate steps to ensure Negroes are included in venires simply so they can be struck because of their race by a prosecutor's use of peremptory challenges." 36

The delayed reconsideration came in Batson v. Kentucky, a radical ruling on peremptories. For the first time, a federal court agreed that an attorney can be forced to explain his or her reason for invoking a peremptory. It provided release from the untenable situation created by Swain. The issue was framed starkly in the "Question Presented" to the Court by Batson's counsel on appeal:

In a criminal case, does a state trial court err when, over the objection of a black defendant, it swears an all-white jury constituted only after the prosecutor had exercised four of his six peremptory challenges to strike all of the black veniremen from the panel in vio- 


\section{Ethnic Studies Review Volume 24}

lation of constitutional provisions guaranteeing the defendant an impartial jury and a jury composed of persons representing a fair cross section of the community?

The "Question" encapsulated the facts. James Kirkland Batson had been charged with burglary and the receipt of stolen goods. At the end of the voir dire the prosecutor, Mr. Gutman, used four of his six peremptories to create, in his words, an "all-white jury." Defense counsel, Mr. Douglas Dowell, moved for dismissal of the panel before it was sworn on grounds that the panel did not represent a cross-section of the community and to use it would be a denial of equal protection. The judge denied the motion to discharge the jury. Batson was tried and duly convicted. The Kentucky Supreme Court upheld the conviction, in 1984, holding that it had "recently reaffirmed [its] reliance on Swain" and because Batson had not shown "systematic exclusion from the jury" he did not have a claim under Swain.37 The Supreme Court disagreed. It reversed Batson's conviction holding that the impaneling of the jury resulted in a denial of equal protection. In ruling that when an objection is lodged against an alleged racially discriminatory use of the peremptory challenge the trial court must examine the validity of the claim, the United Supreme Court continued the incremental reform to make the Sixth Amendment guarantee of trial by a cross-section of the community meaningful for all. In so doing the Court not only reversed Swain but also might have opened a new Pandora's box, creating a second category of peremptory challenges.

\section{Notes}

1 P.L. Murphy, The Constitution in Crisis Time, 1919-1969. (New York: Harper and Row, 1972), p. 413.

2 Batson v. Kentucky, 84 SC 733 (1985); See also McCray v New York, 461 U.S. 970 (1983).

3 Prigg v. Pennsylvania.

4 Ex parte Virginia, 100 U.S. 339 (1880). 
5 Smith v. Mississippi, 162 U.S. 592 (1896).

6 Strauder v West Virginia, 100 U.S. 303 (1880)

7 Neal v. Delaware, 103 U.S. 370 (1881).

8 Virginia v. Rives, 100 U.S. 313 (1880)

9 Giles v. Harris, 189 U.S. 475 (1903).

10 Norris v. Alabama, 294 U.S. 587 (1935).

11 Avery v. Georgia, 345 U.S. 559 (1953).

12 Castaneda v. Partida, 430 U.S. 482 (1977).

13 Swain v. Alabama, 380 U.S. 202 (1965).

14 McCray v. New York, U.S. 103 S. Ct. 2438 (1983). Gilliard v. Mississippi, 104 S. Ct. 340 (1983). Miller v. Illinois and Perry v. Illinois 561 U.S. 961 (1983) Thompson v. United States, 105 S. Ct. 443 (1984).

15 Apodaca v. Oregon, 406 U.S. 404 (1972).

16 Akins v. Texas, 325 U.S. 398 (1945).

17 Hill v. Texas, 316 U.S. 400 (1942).

18 Cassell v. Texas, 339 U.S. 282 (1950). See also Thiel v. Southern Pacific Co., 328 U.S. 217 (1946) in which the Court wrote "jury competence is an individual rather than a group or class matter. That fact lies at the very heart of the jury system. To disregard it is to open the door to class distinctions and discriminations."

19 Hernandez v. Texas, 347 U.S. 475 (1954).

20 People v. Reyes, 9 Cal. 347 (1855).

21 People v. Car Soy, 57 Cal. 102 (1880). 


\section{Ethnic Studies Review Volume 24}

22 Horst v. Silverman, 20 Washington 233, 55 P. 52 (1898).

23 Aldridge v. United States, 283 U.S. (1931).

24 See Ristaino v. Ross, 424 U.S. 589 (1976); Rosales-Lopez v. United States, 451 U.S. 182 (1981); United Bear Runner, 502 F. 2d 908 (8th Cir. 1974); United States v. Diggs, 429 U.S. 852 (1976); and United States v. Walker, 416 U.S. 1994 (1974).

25 Pierre v. Louisiana, 306 U.S.3 354 (1939).

26 Turner v. Fouche, 396 U.S. 346 (1970).

27 Carter v. Jury Commission, 396 U.S. 320 (1970).

28 Peters v. Kiff, 407 U.S. 503 (1972). Also see Powers v. Ohio, 111 S. Ct. (1991).

29 Hearings Before Subcommittee No. 5 of the House Committee on the Judiciary on Miscellaneous Proposals Regarding the Civil Rights of Persons Within the Jurisdiction of the United States, 89th Congress 2nd Session, Series 16 (1966) 1048.

30 H.R. 14765 S 101-186, S 201, S 203(b).

31 People v. Wheeler, 22 Calif. 3d 148 California Reporter 903.

32 Taylor v. Louisiana, 419 U.S. 522 (1975).

33 Commonwealth v. Soares, 377 Mass. 461 and 3444 U.S. 881 (1979).

34 State v. Crespin, 94 N.M. 486, 612 P. 716 (N.M. Ct. App. 1980).

35 Gilliard v. Mississippi, 104 S Ct. 40 (1983)

36 McCray v. New York, 461 U.S. 970 (1983).

37 Batson v Kentucky, 84SC 733-MR. 